\title{
SOME HORMONAL AND BIOCHEMICAL BLOOD INDICES IN PREGNANT BUFFALOES BEFORE AND AFTER RETENTION OF PLACENTA
}

\author{
AMIRA M.M.METWALLY *; ENAS A.H. FARAG* and MAAROUF A.A.** \\ * Dept. of Biochemistry, Animal Health Research Institute, Benha branch. \\ ** Dept of Microbiology, Animal Health Research Institute, Benha branch
}

\section{ABSTACT}

Received at: $31 / 3 / 2013$

This study was carried out in a private dairy farm at Kaliobeia Governorate to investigate the relationship between preparturient hormonal and biochemical changes in pregnant buffaloes and buffaloes with retained placenta (RP). A total of 32 pregnant buffaloes used in this study, blood samples were collected at late

Accepted: 20/5/2013 stage of pregnancy (two week, week before calving and after parturition). Preparturient biochemical examination revealed that 25 animals were around normal levels, while blood picture of seven animals revealed anemia with leucocytosis, lymphopenia and monocytosis associated with oxidative stress as shown by obvious increase in nitric oxide (NO), lipid peroxidase (LPO) and decrease of catalase (CAT), superoxidase dismutase (SOD) ascorbic acid (ASCA) and total antioxidant capacity (TAC) values. In addition there were a significant decrease in level of selenium (Se), vitamin E with low zinc $(\mathrm{Z})$, copper $(\mathrm{Cu})$, iron (Fe) concentration. Hormonal changes showed that increase level of progesteron, cortisol while decrease in estradiol-17 $\beta$. Regular flow up of these animals post parturient revealed that animals considered RP (1-3 days) post calving were subjected to manual removal of there placentae. Therefore this study can put light on prevention of retained placenta is the key to avoid reproductive disturbances. A balanced, limited ration with sufficient amount of antioxidant during the 6-8 week dry period, sufficient daily exercise, sufficiently large clean and comfortable calving areas and proper sanitary procedures during the calving period minimize the chances of retention and infections of reproductive tract.

Key words: Pregnant buffaloes, LPO, Antioxidants, Hormonal changes.

\section{INTRODUCTION}

Retained placenta is the main common reproductive disorders in dairy buffaloes which induced subsequent uterine infection, endometritis, reduction of milk yield and lower conception rate beside decrease market value of animal (Hemingway, 2003 and Semacan and Sevinc, 2005). Although the etiology of retained placenta has been the subject of numerous studies the exact cause is not clear (Joosten and Hesen, 1992 and Wischral et al., 2001). Meanwhile, it was found that various causes of RP have been identified i.e uterine paresis, abortion, late or pre-mature birth, dystocia infections and hormonal disorders beside some vitamin and minearal deficiencies predispose for RP (Ahmed et al., 2009 and Akar and Yeldiz, 2005). According to Brzezinska-Slebodzinsk et al. (1994) and Kankofer (2001 a.) oxidative stress in cow is a contributory factor to increase disease susceptibility since metabolic demand associated with late pregnancy and increase milk production would be expected to increase production and uncontrolled increase reactive oxygen species (ROS) which could be a risk factor for RP (Sordillo, 2005). RP was reported to be associated with oxidative stress in dairy cows (Kankofer, 2001 b). The antioxidant vitamins (e.g vitamin E) is important for improve the fertility of dairy cows (Allison and Laven, 2000). In late pregnancy, the production of free radicals was increased, these elevation in free radical and increasing in oxidative damage may involved in parturition, meanwhile the over increase in the oxidative process after parturition may led to RP and /or postpartum infertility (Toescu et al., 2002). However vascular changes and uterine contractions has been found to play a role in placental release (Laven and Peters, 1996).

This study is a trial to highlight on some parameters as indicators of RP in dairy buffoles.

\section{MATERIALS and METHODS}

Animals and their managements: Thirty two pregnant dairy buffaloes belonging to private dairy farm in Kaliobeia Governorate were used in this 
study. Animals age 4-7 years and were kept under veterinary supervision, general health condition were examined, housed in the same feeding and management condition until end of study. Case history of each animal was recorded. Buffaloes were considered to retain their placenta if it does not drop after at least $12 \mathrm{hrs}$ post calving (Stephen, 2008). Buffaloes with RP showed discolored vulval membranes, foul smelling discharge, in appetence and decrease milk yield.

Sampling: Two blood samples (with and without EDTA) were collected from each animal via jugular vein puncture two week, week before parturition and one week after parturition. Uncoagulated blood samples were used for performing complete blood picture as well as for determination of selenium (Se) values. Serum was separated from coagulated blood samples by centrifugation for assaying biochemical constituents.

Analysis: Complete blood picture including erythrogram and leucogram was carried out according to (Jain, 2000). The serum levels of cortisol, progesterone and oestradiol-17 $\beta$ were determined as described by (Hasler et al., 1976; Xing et al., 1983 and Kubosik, 1984) respectively using validated radioimmunoassay (Diagnostic Products Corportation, Los Angles CA). Trace elements including $\mathrm{Zn}, \mathrm{Fe}$ and $\mathrm{Cu}$ concentrations in diluted serum samples and Se in whole blood samples were determined using atomic absorption spectrophotometry as outline by Varley et al. (1980). Serum calcium was determined according to Gindler and King (1972). Oxidant and antioxidant markers including LPO were estimated according to Buege and Aust (1977), NO (Montgomery and Dymock 1961), CAT (Aebi, 1984), ASCA (Haris and Ray, 1945), R-GSH (Beutler et al., 1963) and TAC (Koracevic et al., 2001) were determined.

Statistical analysis: Data were expressed as means \pm standard error $(\mathrm{M} \pm \mathrm{SE})$. The comparison between the groups was conducted by one way analysis of variance (SPSS, 1993).

\section{RESULTS}

The results of clinical examination of thirty two pregnant buffaloes (two week, week preparturient and week postparturient) showed that seven out of these animals suffered from RP, two of them had history of retained fetal membrane. which retained their placentae for more than $12 \mathrm{hrs}$ post calving and were considered to suffer from RP and the remaining animals dropped their placentae normally within 12 hrs most of the retained groups were subjected to manual removal of their placentae. All data concerning heamatological results were presented in Table (1) while other markers of oxidant, antioxidant and some biochemical in RP showed Table (2).

Table 1: Mean values of some heamatological parameters of pregnant buffaloes before and after retained fetal membrane.

\begin{tabular}{|c|c|c|c|c|}
\hline $\begin{array}{c}\text { Items } \\
\text { parameters } \\
\end{array}$ & $\begin{array}{c}\text { Control } \\
\text { (pregnant) }\end{array}$ & $\begin{array}{c}2 \text { week } \\
\text { (pre parturient) }\end{array}$ & $\begin{array}{c}1 \text { week } \\
\text { (pre parturient) }\end{array}$ & $\begin{array}{c}\text { Retained fetal } \\
\text { membrane }\end{array}$ \\
\hline $\operatorname{RBCs}\left(10^{6} / \mathrm{mm}^{3}\right)$ & $5.9 \pm 0.14^{\mathrm{b}}$ & $5.6 \pm 0.16^{\mathrm{b}}$ & $5.4 \pm 0.12^{b}$ & $4.8 \pm 0.17^{\mathrm{a}}$ \\
\hline $\mathrm{Hb}(\mathrm{gm} / \mathrm{dl})$ & $12.02 \pm 0.177^{\mathrm{d}}$ & $11.02 \pm 0.178^{\mathrm{c}}$ & $9.96 \pm 0.229^{b}$ & $9.06 \pm 0.199^{\mathrm{a}}$ \\
\hline $\operatorname{PCV}(\%)$ & $34.5 \pm 0.769^{b}$ & $32.7 \pm 0.831^{\mathrm{b}}$ & $30.26 \pm 0.573^{\mathrm{a}}$ & $29.38 \pm 0.815^{\mathrm{a}}$ \\
\hline $\operatorname{WBCs}\left(10^{3} / \mathrm{mm}^{3}\right)$ & $6.54 \pm 0.121^{\mathrm{a}}$ & $6.74 \pm 0.178^{a}$ & $7.18 \pm 0.116^{b}$ & $8.45 \pm 0.159^{c}$ \\
\hline $\begin{array}{c}\text { Lymphocytes } \\
\left(10^{3} / \mathbf{m m}^{3}\right) \\
\end{array}$ & $3.2 \pm 0.071^{d}$ & $3.0 \pm 0.07^{\mathrm{d}}$ & $2.7 \pm 0.08^{\mathrm{c}}$ & $2.2 \pm 0.1^{b}$ \\
\hline $\begin{array}{c}\text { Neutrophils } \\
\left(10^{3} / \mathbf{m m}^{3}\right)\end{array}$ & $2.1 \pm 0.07^{\mathrm{c}}$ & $2.3 \pm 0.08^{c}$ & $2.6 \pm 0.08^{c}$ & $3.7 \pm 0.09^{d}$ \\
\hline $\begin{array}{l}\text { Monocytes } \\
\left(\mathbf{1 0}^{3} / \mathbf{m m}^{3}\right)\end{array}$ & $1.1 \pm 0.08^{b}$ & $1.3 \pm 0.07^{b}$ & $1.7 \pm 0.10^{b}$ & $2.5 \pm 0.08^{c}$ \\
\hline $\begin{array}{l}\text { Esinophils } \\
\left(10^{3} / \mathrm{mm}^{3}\right)\end{array}$ & $0.12 \pm 0.007^{\mathrm{a}}$ & $0.07 \pm 0.01^{\mathrm{a}}$ & $0.07 \pm 0.01^{\mathrm{a}}$ & $0.08 \pm 0.01^{\mathrm{a}}$ \\
\hline $\begin{array}{l}\text { Basophils } \\
\left(10^{3} / \mathbf{m m}^{3}\right)\end{array}$ & $0.02 \pm 0.007^{\mathrm{a}}$ & $0.03 \pm 0.02^{a}$ & $0.05 \pm 0.01^{\mathrm{a}}$ & $0.04 \pm 0.01^{\mathrm{a}}$ \\
\hline
\end{tabular}

Values (a-b-c-d) at the same raw followed by different superscript letters were significantly different $(\mathrm{P}<0.05)$. 
Table 2: Mean values of some hormonal and biochemical parameters of pregnant buffaloes before and after retained fetal membrane.

\begin{tabular}{|c|c|c|c|c|}
\hline $\begin{array}{c}\text { Items } \\
\text { Parameters }\end{array}$ & $\begin{array}{c}\text { Control } \\
\text { (pregnant) }\end{array}$ & $\begin{array}{c}\text { 2week } \\
\text { (preparturient) }\end{array}$ & $\begin{array}{c}1 \text { week } \\
\text { (preparturient) }\end{array}$ & $\begin{array}{c}\text { Retained } \\
\text { fetal } \\
\text { membrane }\end{array}$ \\
\hline Progesterone(ng/ml) & $2.6 \pm 0.01^{\mathrm{a}}$ & $2.8 \pm 0.01^{\mathrm{ab}}$ & $3.1 \pm 0.012^{\mathrm{bc}}$ & $3.3 \pm 0.011^{\mathrm{c}}$ \\
\hline Estradiol-17 $\beta(\mathrm{Pg} / \mathrm{ml})$ & $93.4 \pm 2.18^{\mathrm{c}}$ & $89.04 \pm 2.22^{c}$ & $35.10 \pm 0.98^{b}$ & $23.06 \pm 0.83^{\mathrm{a}}$ \\
\hline Cortisol (ng/ml) & $1.38 \pm 0.086^{\mathrm{a}}$ & $1.74 \pm 0.092^{b}$ & $1.94 \pm 0.067^{b}$ & $2.54 \pm 0.121^{\mathrm{c}}$ \\
\hline Catalase (CAT )(U/ml) & $2.1 \pm 0.09^{\mathrm{c}}$ & $1.92 \pm 0.12^{\mathrm{bc}}$ & $1.72 \pm 0.08^{\mathrm{ab}}$ & $1.52 \pm 0.11^{\mathrm{a}}$ \\
\hline $\begin{array}{l}\text { Superoxide dismutase } \\
\text { (SOD) }(\mathrm{U} / \mathrm{ml})\end{array}$ & $32.8 \pm 1.07^{b}$ & $30.6 \pm 1.17^{b}$ & $25.4 \pm 1.21^{\mathrm{a}}$ & $25.4 \pm 1.2^{\mathrm{a}}$ \\
\hline $\begin{array}{l}\text { Total antioxidant capacity } \\
\text { (TAC)(mmol/l) }\end{array}$ & $1.22 \pm 0.12^{\mathrm{c}}$ & $1.12 \pm 0.08^{\mathrm{c}}$ & $0.88 \pm 0.03^{b}$ & $0.58 \pm 0.02^{\mathrm{a}}$ \\
\hline Selenium (ug/100ml) & $8.76 \pm 0.12^{d}$ & $7.60 \pm 0.24^{\mathrm{c}}$ & $6.1 \pm 0.18^{b}$ & $4.46 \pm 0.23^{\mathrm{a}}$ \\
\hline Vitamin E ( ug/100ml) & $60.44 \pm 1.03^{d}$ & $57.16 \pm 0.94^{\mathrm{c}}$ & $52.56 \pm 0.80^{b}$ & $49.74 \pm 0.98^{\mathrm{a}}$ \\
\hline $\begin{array}{l}\text { Lipid peroxidation (LPO) } \\
(\mathrm{nm} / \mathrm{ml})\end{array}$ & $0.99 \pm 0.045^{\mathrm{a}}$ & $1.74 \pm 0.093^{b}$ & $2.4 \pm 0.071^{\mathrm{c}}$ & $2.56 \pm 0.092^{c}$ \\
\hline Nitricoxide(NO)(nM/ml) & $22.5 \pm 0.62^{\mathrm{a}}$ & $27 \pm 0.37^{\mathrm{b}}$ & $29.3 \pm 0.34^{\mathrm{c}}$ & $31.7 \pm 0.52^{\mathrm{d}}$ \\
\hline Ascorbic acid ( ug/L) & $131.86 \pm 1.56^{\mathrm{d}}$ & $118.84 \pm 2.34^{\mathrm{c}}$ & $103.5 \pm 1.82^{b}$ & $83.0 \pm 1.79^{\mathrm{a}}$ \\
\hline Zinc ( ug/dl) & $139 \pm 1.69^{d}$ & $130 \pm 1.41^{\mathrm{c}}$ & $122 \pm 1.41^{b}$ & $115 \pm 1.41^{\mathrm{a}}$ \\
\hline Copper ( ug/dl) & $78 \pm 1.70^{\mathrm{c}}$ & $72 \pm 1.70^{b}$ & $69.8 \pm 1.99^{b}$ & $64.2 \pm 1.43^{\mathrm{a}}$ \\
\hline Iron (ug/dl) & $140.4 \pm 1.63^{c}$ & $132 \pm 1.41^{b}$ & $119.6 \pm 1.63^{\mathrm{a}}$ & $115 \pm 1.70^{\mathrm{a}}$ \\
\hline
\end{tabular}

Values(a-b-c-d) at the same raw followed by different superscript letters were significantly different $(\mathrm{P}<0.05)$

\section{DISCUSSION}

Retained placenta is identified as major importance reproductive abnormality of cows and buffaloes. It can be substantial risk factor for toxic puerperal metritis, it couses significant economic losses, as many RP buffaloes develop metritis and suffer from infertility (Azawi and Taha 2002 and Azawi 2006). In this study animals with RP suffered from anemia as indicated by the significant decrease in RBCs, $\mathrm{Hb}$ and $\mathrm{PCV}$, also there is a leucocytosis accampanied by lymphopenia, neutrophilia and monocytosis these may be attributed to inflammation and increase monocytes for scavening of cell debris (Sivaraman et al., 2003). Increase progesteron in preparturient period in our results (Table 2 ) could be a major factor contributing to the pathogenesis of retained fetal membrane (RFM) in buffaloes, however normally increasing estrogen and decreasing progesterone activities lead to multiple changes which is accompanied by increasing prostaglandin synthesis and mainly to a rise oxytocin receptor concentration in the myometrium these basic changes are necessary for subsequent placental separation and expulsion (Husslein, 1984; Sabry et al., 1997 and Michal and Hanna, 2006). Increased progesterone level in RP may be due to failure of placenta to produce specific steroidal enzymes that help in progesterone metabolism and its conversion to esterogen (Matton and Dufour, 1987), which in turn may induce the accumulation of immunosuppressive proteins in the uterine lumen and make the uterus susceptible to infection and persistence bacteria (Konigsson et al., 2002).

It has been documented that RFM associated with the presence of uncontrolled eleveted level of reactive oxygen species (ROS) which may disturb physiological processes leading to expulsion of the placenta (Kankofer, $2001 \mathrm{a}, \mathrm{b}$ ), when free radical generation exceeds the body's antioxidant production capacity, oxidative stress develops Roth, (2000) reported that estradiol has a potant antioxidant activities. The periparturient significant increase in estradiol-17 $\beta$ concentration is in agreement with that results of Eissa et al. (1995) and Badr et al. (2001).

The rise in cortisol (Table 2) stimulates the conversion of placentally derived progesterone to estradiol by activating the placental enzyme17 $\alpha$ hydroxylase which hydroxylates progesterone via androstenedione to estradiol $17 \beta$. The consequences of the rise in estradiol $17 \beta$ and decline of progesterone in prepheral circulation have a triple effects, first estradiol has a direct effect upon the myometrium increasing its responsiveness to oxytocin, second they produce softening of cervix by altering the structure of collagen fibers, third they act upon the cotyledoncaruncle complex to stimulate the production and release of $\mathrm{PGF}_{2 \alpha}$ (Grunet, 1986 and Horta, 1988). 
In the current study it was found that peroxidative indices (LPO and NO) are an indicator of over production of free radicals and cellular damage which were elevated during the last two weeks of pregnancy compared with non pregnant animals in the same time the level of antioxidant (CAT, ASCA, SOD TAC, selenium and vitamin $\mathrm{E}$ ) were decreased these mean that oxidative stress and exhaustion of the antioxidant were involved in the late stage of pregnancy. These results agree with Megahed et al. (2006); Ahmed et al. (2009) and Toescu et al. (2002) who reported that late pregnancy was associated with the formation of susceptible oxidisable particles and an increase in oxidative damage. Antioxidative defense mechanisms are complex net work used to scavenge ROS. Kankofera et al. (2005) recorded that RP in buffaloes is related to imbalance between production and neutralization in ROS. Moreover, it was suggested that alterations in antioxidative capacity are related to changes in hormonal levels which appear close to parturition. Clinically important symptoms are defined as the disturbances in steroid hormones as well as prostaglandin $\mathrm{F}_{2}$ a concentration (Leidl and Rockel, 1980 and Heuwieser and Grunert, 1987). In this study significant decrease was recorded (Table 2) in selenium, vitamin $\mathrm{E}, \mathrm{Zn}, \mathrm{Cu}$ and $\mathrm{Fe}$, similar finding were reported by Segerson et al. (1980); Ahmed et al. (1999) and EL-Khadrawy and ELEkhnawy (2005) who found that inadequate concentrations of selenium and vitamin $\mathrm{E}$ in the diet increased oxidative stress, production of lipid peroxidase and the incidence of RFM. Se, $\mathrm{Cu}$ and $\mathrm{Zn}$ are trace minerals required for functioning of enzymes involved in the antioxidant defense system. Se is known to be incorporated in the glutathione peroxidase performing the antioxidative defense of the body by eliminating hydrogen peroxides (Kommisrud and Vatn, 2005). $\mathrm{Cu}$ and $\mathrm{Zn}$ are involved in the antioxidant system via its involvement in superoxidase dismutase (SOD) and ceruloplasmin. Copper, $\mathrm{Zn}$ and SOD are responsible for dismutation of superoxide radicals to hydrogen peroxide in the cytosol (Halliwell and Gutteridge, 1999).

It could be concluded that retention of placenta is a serious problem resulted in uterine infection and toxic puerperal metritis. Also it has an adverse effect on some hormonal and biochemical parameters. So supplementation of dam with a balanced ration containing adequat amount of antioxidant during late stage of pregnancy beside that sufficient daily exercise, sufficient large clean and comfortable calving areas and proper sanitary procedures during the calving period is advised to minimize PR and infection of the reproductive tract.

\section{REFERANCES}

Aebi, H. (1984): Catalase in vivo .Method of Enzymology.105: 121-126.

Ahmed, W.A.; EL-Ekhnawy, K.L; Dessouky, H.M; Zaabal, M.M. and Ahmed, Y.F. (1999): Investigation on retained fetal membranes in Friesian cows in Egypt. J. comp. path. and clinical path.12: 160-177.

Ahmed, W.M; EL-Ekhanay, K.I; EL-Nattat, W.S.; Dessouky, H.M. and EL-Khadrawy, H.H. (2009): Investigation on calving associated problems in a Friesian herd in Egypt with special reference to some prophylactic trials. J. Basic physiol.,3: 65-87.

Akar, Y. and Yeldiz, H. (2005): Concentration of some minerals in cows with retained placenta and abortion. Turkish J. Vet. Anim. Sci., 29: 1157-1162.

Allison, RD. and Laven, R.A. (2000): Effect of vitamin $\mathrm{E}$ supplementation on the health and fertility of dairy cows: a review. Vet. Res. 147: 703-708.

Azawi, O.I. and Taha, M.B. (2002): Clinical and bacteriological study of endometritis in Iraqi buffaloes. Iraqi J. Vet., Sci., 16: 167-178.

Azawi, O.I. (2006): Clinical, bacteriological and pathological studies of uterine infections of Iraqi buffalo cows. ph.D Thesis, College of Veterinary Medicine University of Baghdad pp: 45-138.

Badr, H.M.; Ashour, A.M. and Solouma, G.M. (2001): Serum concentration of progesterone and estradiol-17 $\beta$ during late gestation,parturition and postpartum and its relation to ovarian activits in Egyption Buffaloes. AL-Azhar J. Agric. Res. Vol. 33: pp.27- 44.

Beutler, E.O. Duron and M.B. Kelly, (1963): A Manual of biochemical methods.Grune and Straiton. N.Y.

Brzezinska-Slebodzinska, E.; Miller, J.K.; Quigley, J.D. and Moore, J.R. (1994): Antioxidant status of dairy cows supplement prepartum with vitamin E and selenium. J. Dairy Sci. 77: 3087-3095.

Buege, J.A. and Aust, S.D. (1977): Microsomal lipid peroxidation in: Methods in enzymology eds. Fleischer S. and Pocker L. Vol.52, pp.302-310. Academic press, New York.

Eissa, H.M.; EL-Belely, M.S.; Ghoneim, I.M. and Ezzo, O.H. (1995): Plasma progesterone, estradiol17 beta oestrone sulphate, corticosteroids and a metabolite of PGF2 alpha: evolution throughtout pregnancy, before during and after parturition buffalo cows. Vet. Res.,26(4): 310-318. 
EL-Khadrawy, H.H. and EL-Ekhnawy, K.I. (2005): Effect of placental retentionon some antioxidant concentratios and hormone levels and subsequent reproductive performance on Friesian cows in Egypt. J. Egypt. Vet. Med. Assoc., 65(3): 79-87.

Gindler, M.E. and King, J.D. (1972): Rapid colorimetric determination of calcium in fluids with methyl thymol blue. Am. J. clin. path., 58: 376.

Grunert, E. (1986): Etiology and pathogenesis of bovine retained placenta. In: Morrow, D.A. (ed), Current Therapy in Theriogenology. $2^{\text {nd }}$ edition. W.B. Saunders, Philadelphia, 237-242.

Halliwell, B. and Gutteridge, J.M.C. (1999): Free radical in biology and medicine. $3^{\text {rd }}$ Edn. Oxford University Press, New York, USA.

Haris, L.T. and Ray, S.N. (1945): Determination of ascorbic acid. Lancet, 71: 462

Hasler, M.J.; Painter, K. and Niswender, G.D. (1976): An 1251 labeled cortisol radioimmunoassay in which serum binding proteins are enzymatically denaturated. Clin. Chem. 22: 1850-1854.

Hemingway, R.C. (2003): The influences of dietary intakes and supplementation with selenium and vitamin $\mathrm{E}$ on reproduction diseases and reproductive efficiency in cattle and sheep. Vet. Res. Communications., 27: 159-174.

Heuwieser, W. and Grunert, E. (1987): Steroid hormone profile in der Nachgeburtsphase beim rind, Dtsch Tierarzti Wochenschr, 104: 13-14.

Horta, A.E.M. (1988): ProstaglandineF2 $\alpha$ and prostacyclin imbalance in cows with placental retention: new findings. Ann. Resh. Vet., 17: 395-399.

Husslein, P. (1984): The importance of oxytocine and prostaglandins to the mechanism of labor in humans. Klin. Wochenschr. Suppl., 155: 1-32.

Jain, N.C. (2000): Schalm's Veterinary Hematology $5^{\text {th }}$ Edn. Lee and Febiger. Philadelphia. USA.

Joosten, I. and Hensen, E.J. (1992): Retained placenta: an immunological approach. Anim. Repord. Sci., 28: 451-461.

Kankofer, M. (2001a): The levels of lipid peroxidation products in bovine retained and non retained placenta. Prostaglandins, Leukotrienes and Essential Fatty Acids, 64(1): 33-360.

Kankofer, M. (2001b): Anti-oxidant defense mechanism against reactive oxygen species in bovine retained and non retained placenta: activity of glutathione peroxidase, glutathione transferase, catalase and superoxide dismutase. Placenta, 22: 466-472.

Kankofera, M.; Lipko, J. and Zdunczyk, S. (2005): Total antioxidant capacity of bovine spontaneously released and retained placenta. Pathophysiology. 11: 215-219.
Kommisrud, E.O.O. and Vatn, T. (2005): Blood selenium association with healthy and fertility in Norwegian dairy herds. Acta. Veterinaria Scandinavica. 46: 229-240.

Konigsson, K.H. Gustafsson and H. Kindahl, (2002): 15-Ketodihydro-PGF(2alpha), progesterone and uterine involution in primiparous cows with induced retained placenta and post-partal endometritis treated with oxytetracycline and flunixin. Reproduction of Domestic Animal, 37: 43-51.

Koracevic, D.G.; Koracevic, V.; Djordjevic, S.A. and Cosic, V. (2001): Method of the measurement of antioxidant activity in human fluids. J. Clin. Pathol., 54: 356-361.

Kubosik, N.D. (1984): Evaluation of direct solid phase radioimmunoassy for progesterone. Clin. Chem., 30: 384. Cited in diagnostic products corporation pamphlet.

Laven, R.A. and Peters, A.R. (1996): Bovine retained placenta: Etiology, pathogenesis and economic loss. Vet. Rec., 139: 465-471.

Leidl, W.D.H. and Rockel, P. (1980): Investigation on PGF2 concentration in the maternal and fetal cotyledons of cows with and without retained fetal membranes. J. Vet. Med. Assoc. 27: 691-696.

Matton, P.V.A. and Dufour, J. (1987): Corpus luteum activity and prostaglandin levels after parturition in cows with retained fetal membranes. Candian J. Anim. Sci. 67: 21-26.

Megahed, G.A.; Mamdouh, M. Anwar and El-Ballal, S.S. (2002): Superoxide dismutase. Nitric oxide and lipid peroxide productions and it,s relation to apoptotic changes and serum progesterone hormone level during physiological lifespan of buffalo, s corpora lutea. Minufyia Vet. Med. J. 2,(1)99-112.

Michal, K.M.E. and Hanna, M. (2006): Some hormonal and biochemical blood indices in cows with retained placenta and puerperal metritis. Bulletin of the veterinary institute in pulawy. 50: 89-92.

Montgomery, H.A. and Dymock, J.F. (1961): Determination of nitric oxide. Analysis, 86: 415.

Roth, E. (2000): Oxygen free radicals and thrie clinical implications. Acta Chirugica, 36: 302-305.

Sabry, H.A.; Shalaby, S.L. and Hassan, S.G. (1997): Retained placenta in an imported Friesian herd under Egyptian condition. Vet. Med. J., Giza, 45: 121-127.

Segerson, E.C.; Riviere, G.; Bullock,; Thimaya, S. and Ganapathy, S.N. (1980): Uterine contractions and electrical activity in ewes treated with selenium and vitamin E. Biol. Reprod., 23: 1020-10280 
Semacan, A. and Sevinc, M. (2005): Liver function in cows with retained placenta. J. Vet. Anim. Sci. 29: $775-778$.

Sivaraman, T.; Shanmugasundaram, S.; Arunachalam, S. and Sivakumar, T. (2003) :Blood profile constituents associated with production diseases in Jersey crossbred cows. Indian J. Anim. Sci., 73-44-47.

Sordillo, L.M. (2005): Factors affecting mammary gland immunity and mastitis susceptibility.Livestock production Science. 98: 89-99.

SPSS (1993): Statistical package for Social Science., SPSS/E base 9.0 User's guide., Chicago, IL, USA.

Stephen, J.L. (2008): A postmortem uterine disease and dairy herd reproductive performance: A review. Vet. J., 176: 102-114.
Toescu, V.; Nuttall, S.L.; Martin, U.; Kendall, M.J. and Dunne, F. (2002): Oxidative stress and normal pepregnancy. Clin Endocrinol (oxf), 57(5): 609-613.

Varley, H.; Wenlock, A.H.G. and Bell, M. (1980): Practical clinical chemistry, I:General topics commoner test $5^{\text {th }}$ Edn William Heinemann Medical Books Ltd, London, UK.

Wischral, A.; Verreschi, I.T.N.; Lima, S.B.; Hayashi, L.F. and Barnabe, R.C. (2001): Pre-parturation profile of steroids and prostaglandin in cows with and without fetal membrane retention. Anim. Reprod. Sci., 67: 181-188.

Xing, S.; Cekan, C.Z. and Diczfalusy, U. (1983): Validation of radioimmunoassy for esterdiol17 $\beta$ by isotope dilution mass spectrometry and by a test of radiochemical purity. Clin. Chem. Acta, 135: 189. Cited in diagnostic products corporation pamphlet.

\section{بعض المؤشرات الهرمونية والكيميائية فى الجاموس العثار قبل وبعد الاصابة باحتباس المشيمة \\ أمبرة محمد محمود متولي ، ابياس عبل الرحمن حسن فراج ، أحمد عفيفي عبد الغفار معروف}

اجريت هذه الدر اسة على 32 من الجاموس العشار في احدى المز ارع الخاصة بمحافظة القليوبية يتر اوح عمر ها ما بين 4

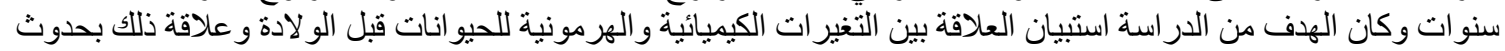

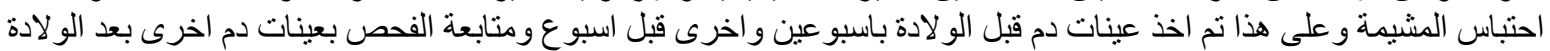

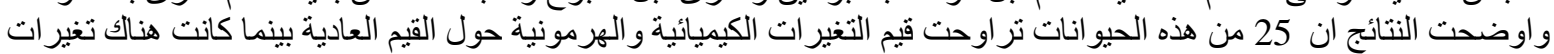

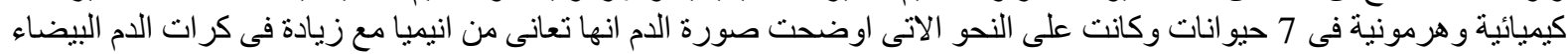

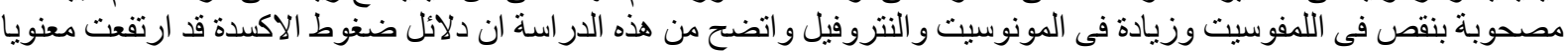

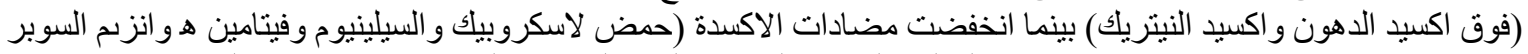

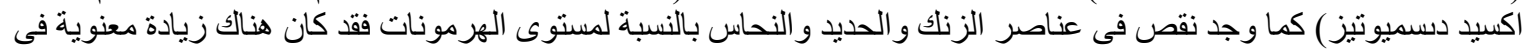

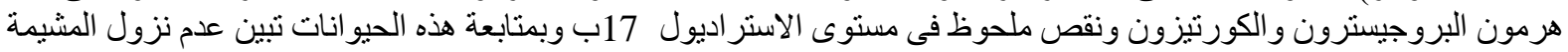

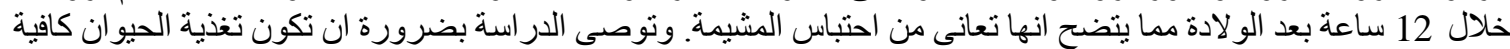

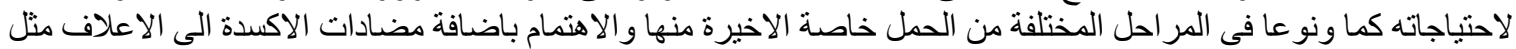
السيلينيوم وفيتامين هـ كإجر اء وقائى ضد الئ اجهاد الاكسده بهدف التغلب على العديد من الاضطر الابات التناسلية المرتبطة باجهاد الاكسده

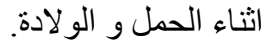

